\title{
JOURNALISTIC INNOVATION: HOW NEW FORMATS OF DIGITAL JOURNALISM ARE PERCEIVED IN THE ACADEMIC LITERATURE
}

Carlos Lopezosa (UPF) Lluís Codina (UPF) Ariadna Fernández-Planells (UPV), Pere Freixa (UPF) carlos.lopezosa@upf.edu , 1luis.codina@upf.edu, arferpla@upv.es , pere.freixa@upf.edu

\begin{abstract}
The news media are constantly introducing innovations in their presentation formats, transforming as they do journalistic genres and creating entirely new ways of telling and consuming news. These changes are also closely reflected in academic research on journalism. This article carries out a systematic review of the literature analyzing the following new journalistic formats: structured journalism, immersive journalism, $360^{\circ}$ video reports, virtual reality and augmented reality applied to journalism, newsgames and docugames. To do so, the scientific production examining these formats is first analyzed to determine the academic impact of these studies, while identifying their characteristics and tracking their evolution over time. Second, the leading researchers in this field are identified and interviewed to ascertain their opinion about the future of journalism and changing trends in journalistic formats. The results show that the number of academic publications about journalistic innovation peaked in 2019, above all in the three journals - Digital Journalism, Journalism Practice and Profesional de la Información - that lead the way in this discipline. The 23 academics interviewed reported that innovation impacts primarily on four aspects of journalism: information and content; audience; methods and resources and news media companies.
\end{abstract}

\section{Keywords}

systematic literature review, journalistic innovation, structured journalism, immersive journalism, augmented reality, virtual reality, $360^{\circ}$ videos, newsgames

Article accepted by: Journalism (SAGE)

This is an electronic version of an article published in Lopezosa C, Codina L, Fernández-Planells A, Freixa P. Journalistic innovation: how new formats of digital journalism are perceived in the academic literature. Journalism. 2021. 18 p. DOI: 10.1177/14648849211033434

\section{Reuse}

This is an Open Access article distributed under the terms of the Creative Commons AttributionNonCommercial-ShareAlike License (CC BY-NC-SA 4.0), which permits copying, adaptation and redistribution for non-commercial purposes, provided the contribution is distributed under the same licence as the original, and the original work is properly cited https:/creativecommons.org/licenses/bync-sa/4.0/ 


\section{JOURNALISTIC INNOVATION: HOW NEW FORMATS OF DIGITAL JOURNALISM ARE PERCEIVED IN THE ACADEMIC LITERATURE}

\section{Introduction}

Journalistic genres are rapidly being transformed and, at the same time, the news media are exploring entirely new ways of telling and consuming news. To mention just two examples, some media outlets have begun publishing immersive reports, in which readers can take on the role of co-producers, while others are publishing news stories that transform themselves into cell phone video games, in which readers interact with the story as they advance through its various levels.

Academic research has not turned a blind eye to these changes and there is already a highly significant corpus of work that examines the significance and scope of journalistic innovation from a range of different points of view. However, because of the multifaceted nature of this innovation and because of the diversity of methodologies being employed, it is not easy to summarize the outcomes of research in this field. Here, in an attempt at rectifying this, we adopt a systematic approach to the review and analysis of academic studies of journalistic innovation.

The primary goal of this article is to identify the principal characteristics of academic studies examining innovations in digital journalism formats. We seek to achieve this objective primarily by undertaking a systematic review of this corpus of academic literature (Hart 2008; Booth et al. 2012). In addition, we set ourselves the following more specific goals:

1) the determination of the parameters, dimensions and specific variables used in the research methodologies and protocols of journalistic innovation studies;

2) the identification of the structural characteristics of the research community that publishes on this topic;

3) evidence-based contributions to the debate concerning the definition of journalistic innovation and the most significant characteristics of these new journalistic formats.

To achieve these goals, we have adopted the framework of 'Search, Appraisal, Synthesis, and Analysis' or SALSA (Hart, 2008; Booth et al., 2012) in order, first, to locate and appraise and, second, to undertake a synthesis and analysis of academic studies of the following innovative formats: structured journalism, immersive journalism, which includes virtual reality and augmented reality and $360^{\circ}$ video reports, newsgames and docugames. Finally, in order to triangulate this evidence, interviews were conducted with a panel of experts, considering as such, for the purposes of this research, the authors previously identified in the literature review.

\section{Theoretical framework}

The theoretical framework for the review conducted here is based on the definition of digital journalism offered by Steensen and Westlund (2021) in their seminal study, according to which: "Digital journalism is a phenomenon and practice of selecting, interpreting, editing, and distributing news about public affairs; it is linked to digital technologies and has a symbiotic relationship with its audiences". Innovations in journalism have led to the emergence of new ways of doing journalism and of consuming news. Traditional forms of journalism, adapted to digital platforms, share the stage today with immersive and structured journalism, gamified content and $360^{\circ}$ videos, among many others.

Seen in this light, academics around the world have studied the phenomenon of journalistic innovation from a range of different perspectives. Some have done so by proposing a categorization of new ways of telling the news, placing the focus on the audiovisual as opposed to the textual (Trillo-Domínguez and 
Alberich-Pascual, 2017), while others have studied it in terms of interactivity (Barredo-Ibáñez and DíazCerveró, 2017), and, even, the newly emerging journalistic skills (Ramírez et al., 2016; Çatal, 2017).

Of course, this list does not exhaust all the possibilities. We should not overlook those authors that have studied journalistic innovation by highlighting the contributions of immersive journalism. Here, numerous studies have focused on the subjectivity of the receiver, perceptions of credibility and the empathy that the format provokes in the reader (Sundar et al., 2017; Sánchez-Laws, 2020). These works are based on the analysis of especially significant case studies, including for example, reports on sexual harassment (Steinfeld, 2020) and the visualization of violent content (Mañas-Viniegra et al., 2020). Similarly, immersive journalism has been studied from a theoretical and conceptual point of view (BaíaReis et al., 2018) and from a more practical perspective through the undertaking of case studies (Vaz and Tejedor, 2019), the analysis of reports on the conflict in Syria (Sacco et al., 2018; Van Damme et al., 2019) and the refugee crisis (Steed et al., 2018), among others.

We should also mention research studies that have focused on laboratories of journalistic experimentation and innovation, a line of research that has allowed the classification of innovation in different areas, including, innovations in presentation formats, something that is of specific concern to us here (Salaverría, 2015; García-Avilés, 2018, 2021; Carrión and Coronel-Salas, 2019), among others. As a result of this work, frameworks have been proposed for application to immersive journalism that capture the requirements for visualizing immersive approaches (Niblock, 2015; Hardee and McMahan, 2017), exploit these characteristics as a method for telling the news and narrating what is going on in the world (Domínguez-Martín, 2015) and reveal the potential of immersive journalism as an information tool (Jones, 2017).

Other (relatively) recent fields of journalistic innovation include those of structured journalism and computational journalism. Structured journalism involves the development of a new form of narrative that links and/or contrasts in an interactive fashion the latest data with archived data. Academic studies have focused mainly on its definition and its characteristics (Freixa et al., 2017), the processes of atomization and encoding of information (Jones and Jones, 2019), and the infrastructure and procedures employed in its execution (Graves and Anderson, 2020). Studies of computational journalism have sought to identify the common bases of different computational approaches to journalism (Caswell, 2019), describing their uses and scope (Vállez and Codina, 2018) and expanding their academic study by conducting experiments in the mass media to atomize news in an automated fashion using algorithms (Jones and Jones, 2019).

Indeed, closely related to computer journalism is automated journalism. This has been studied in academia from different perspectives. Some scholars (Caswell and Dörr, 2018; Kishore et al., 2018) have focused on examining automated journalism in terms of its characteristics and limitations, highlighting, for example, its functionality in the absence of data models sufficient to encode journalistic knowledge and when moving from simple descriptions to richer, more complex narratives, among others.

Academic studies of journalistic innovation have also analyzed data journalism and interactive journalism, identifying considerable transformations in both visual journalism and photojournalism. The focus here has been placed not in photojournalism as a new format but in the innovations and transformations introduced on the format linked to the digital context. In the case of data journalism, studies have looked at both its potential and the challenges it faces: the visualization of data and the use of infographics (Engebretsen, 2020; Túñez-López and Nogueira, 2017; Herrero-Solana and RodríguezDomínguez, 2015), the relationship between journalist and audience (Appelgren, 2019; Anderson and Borges-Rey, 2019; Fernández-Medina et al., 2018), the quality of data journalism projects (Young et al., 2018) and their narrative dimension (Weber et al., 2018). Visual journalism and innovations in photojournalism have been studied from the point of view of privacy and the effect of visual journalism on its subjects (Thomson, 2019), the factors of production and the cultural conditions involved in the interactions between photographers and those photographed (Thomson and Greenwood, 2017), the challenges of photojournalism in the context of the adoption of digital technologies and the new economic 
realities of the journalism sector (Láb and Štefaniková, 2017) and the narrative and the effect of photojournalism on news output (Thomson, 2018).

In addition to these new trends, another key element for the development of journalistic innovations has been the emergence of audiovisuals linked to new technologies. Researchers in the field of communication, appreciative of the characteristics of this technological context, have undertaken a variety of studies in this regard, focusing, above all, on $360^{\circ}$ videos, virtual reality and augmented reality. At the conceptual and theoretical level, the normative limits of the objectivity and precision of $360^{\circ}$ degree journalism have been analyzed (Aitamurto, 2019), interactive annotation techniques have been proposed for $360^{\circ}$ videos that allow the use of traditional video editing techniques to add content to immersive videos (Meira et al. 2016), a model has been created to develop content analysis for $360^{\circ}$ degree video news, (Benítez-de-Gracia and Herrera-Damas, 2018) and tools have been developed to improve the transmission of $360^{\circ}$ degree videos (Sassatelli et al., 2020).

At a more practical level, a number of different case studies have been undertaken of the journalistic use of $360^{\circ}$ videos. Some of the most interesting are those reported by Palmer (2020), who studies the operation of the $360^{\circ}$ video content of The New York Times focused on human rights issues, analyzing whether this content contributes to a greater sense of telepresence; by Vázquez-Herrero et al. (2019), who identify $360^{\circ}$ video initiatives in the Argentine media; by Benítez-de García and Herrera-Damas (2018), who analyze $360^{\circ}$ video immersive journalism projects carried out in the Spanish media; and, finally, by Pérez-Seijo (2018), who examines the organization strategies of the $360^{\circ}$ videos made by European public broadcasters on their websites and YouTube channels.

Similarly, various studies have concerned themselves with examining virtual reality, focused on the effects that this technology has on the perception of the news in terms of its credibility and audience opinions (Kang et al., 2019; Hendriks, 2019; Herranz de la Casa et al., 2019; Yang et al. 2019; Mabrook and Singer, 2019), its content and communicative models (Paíno-Ambrosio and Rodríguez-Fidalgo, 2019; Barreda-Ángeles, 2018), user experience (Shin and Biocca, 2018) and its interactive narrative possibilities (Toursel and Useille, 2019). There have also been academic studies of augmented reality, in which scholars have sought to characterize this type of media reporting (Azkunaga et al., 2019; Parra et al., 2017) and examine its use as a narrative tool (Meneses-Fernández and Martín-Gutiérrez, 2016).

Other genres that have emerged as a result of journalistic innovation and new technologies include newsgames, docugames and gamified content. A number of different academic studies have also focused their attention on these genres, which combine interactive information with video game mechanics. Some of these studies have analyzed the specific elements and gaming dynamics used by different media, mainly in examining reports focused on sport (Rojas-Torrijos, 2020; González-Díez et al., 2019), political corruption (Gómez and Cabeza, 2016), human rights (Plewe and Fürsich, 2018) and interactive documentaries (Vázquez-Herrero and López-García, 2017). Studies have also been carried out examining the viability of using newsgames in university education and for journalistic training (Siitonen et al., 2019), analyzing newsgames in terms of their usability and understanding their ergonomics and parameters, such as pace and strategy, for playing the game (Teixeira et al., 2015) and determining their limitations and potential for gamification (Meier 2018).

Finally, there exists another type of initiative in journalistic innovation, unrelated to genres and new journalistic trends, and which involves the development of tools to debunk fake news. Indeed, various studies have addressed this phenomenon in recent years, most notably, those that analyze digital tools and technologies to expose fake news stories (Graves and Anderson, 2020; Kanozia, 2019) and those that seek to define an appropriate system for the automatic detection of fake news (Lara-Navarra et al., 2020).

\section{Materials and methods}


In order to carry out our study, we employed a methodological triangulation based on a systematic literature review complemented by a series of interviews with experts, identified in this prior review of the literature. Below, we explain in detail how the corpus of documents comprising the subject of our analysis was obtained. We also report its corresponding metrics and the method adhered to in interviewing experts in this field. The results of the systematic review allowed us to create and establish the theoretical framework, determine the evolution of academic publications examining new journalistic formats and identify possible interviewees. The systematic review was undertaken following the SALSA Framework (see Table I) (Hart, 2008; Grant and Booth, 2009; Booth et al., 2012). Even as we knew that the proposed search queries could potentially generate some overlaps and repetition in the search results, queries were defined broad enough in order to detect the maximum number of academic publications related to journalism innovation and its formats.

\begin{tabular}{|c|c|}
\hline \multicolumn{2}{|r|}{ Application of the SALSA Framework } \\
\hline Step & Criteria \\
\hline \multirow[t]{3}{*}{ Search } & Databases: Scopus and Web of Science \\
\hline & 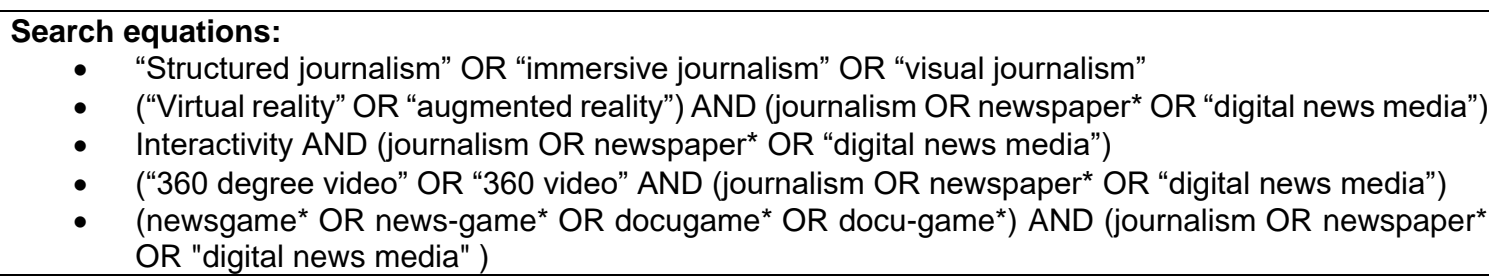 \\
\hline & Period of publication: $2015-2020$ \\
\hline \multirow[t]{2}{*}{ AppraisaL } & $\begin{array}{l}\text { Initial number of documents: } 275 \\
\text { Final number (N) after applying inclusion/exclusion criteria: } 67\end{array}$ \\
\hline & $\begin{array}{l}\text { Inclusion/exclusion criteria: elimination of false positives, articles with an IMRaD or similar structure } \\
\text { (explicit method and presentation of results) }\end{array}$ \\
\hline Synthesis & Narrative synthesis based on the analyses carried out. \\
\hline Analysis & $\begin{aligned} \text { Components: } \\
\text { - Object of study } \\
\text { - Objectives } \\
\text { - Questions/Problems/Hypotheses } \\
\text { - Methodology }\end{aligned}$ \\
\hline
\end{tabular}

Table I. Adapted from the SALSA Framework (Grant and Booth, 2009; Booth et al., 2012).

Once the corpus of documents had been obtained, they were analyzed by applying the same analytical scheme. Each article was read, a synthesis was made and, a bibliometric analysis was completed. To do this, we used the advanced analytical tools provided by Scopus and Web of Science (WoS) for each of the search equations applied. The indicators analyzed by the latter are presented below.

\begin{tabular}{|c|c|}
\hline Indicator & Description \\
\hline Overview of the total number of documents & $\begin{array}{l}\text { Number of articles obtained after applying each of the search } \\
\text { equations }\end{array}$ \\
\hline Leading journal in terms of the number of articles published & $\begin{array}{l}\text { Journals indexed in WoS and/or Scopus with the highest number of } \\
\text { articles about the new journalistic formats analyzed }\end{array}$ \\
\hline Leading author in terms of the number of articles published & $\begin{array}{l}\text { Authors publishing the highest number of articles according to both } \\
\text { the WoS and Scopus search equations }\end{array}$ \\
\hline Leading institution in terms of the number of articles published & $\begin{array}{l}\text { Institutions with the highest number of articles published according } \\
\text { to both the WoS and Scopus search equations }\end{array}$ \\
\hline Countries with highest number of publications & $\begin{array}{l}\text { Countries with the highest number of articles published according to } \\
\text { both the WoS and Scopus search equations }\end{array}$ \\
\hline $\begin{array}{l}\text { Percentage of articles published according to specific area of } \\
\text { knowledge }\end{array}$ & $\begin{array}{l}\text { Specific topics addressed by the articles published according to both } \\
\text { the WoS and Scopus search equations }\end{array}$ \\
\hline Main funders of these articles & Main public and private institutions funding these studies \\
\hline Evolution of citations 2015-2020 & Evolution of citations between January 2015 and April 2020 \\
\hline
\end{tabular}

Table II. Bibliometric indicators analyzed taken from the advanced analytical tools of Scopus and WoS. 
Finally, semi-structured interviews were carried out (Coller, 2000), focused on two questions sent to the authors of the academic papers analyzed. Here, we adhered to the procedure of the so-called 'criteria questions' (Valles, 2002) or selection condiction, taking into consideration, among other matters, who is in possession of the relevant information and who is most likely to be willing to respond. On this basis, the questions were sent to the 118 authors of the articles in the corpus of documents. A total of 23 responses were received (see Table III).

\begin{tabular}{|l|}
\hline \multicolumn{1}{|c|}{ TABLE OF INTERVIEWEES } \\
\hline Adriana Paíno \\
\hline Ana Gabriela Nogueira \\
\hline António Baía Reis \\
\hline Bissie Anderson \\
\hline Daniel Barredo Ibanez \\
\hline David Caswell \\
\hline Enrique Alfonso Sánchez Pérez \\
\hline Ester Appelgren \\
\hline Jordi Alberich Pascual \\
\hline Juan Carlos Marcos Recio \\
\hline Mari Vállez Letrado \\
\hline María Dolores Meneses Fernández \\
\hline Maribel R. Fidalgo \\
\hline Mario Pérez-Montoro \\
\hline Meier, Klaus \\
\hline Seok Kang \\
\hline Valentina Proust \\
\hline T.J. Thomson \\
\hline Xose López García \\
\hline Sameer Kishore \\
\hline Francisco Javier Paniagua Rojano \\
\hline Enrique Núñez Mussa \\
\hline Ana Luisa Sánchez Laws \\
\hline
\end{tabular}

Table III. Authors that participated in the semi-structured interviews

The interviews, conducted by email, comprised two questions. These, together with their corresponding rationale, are listed in the table below:

Table of questions and their corresponding objectives

\begin{tabular}{|l|l|}
\hline Question & Objectives \\
\hline $\begin{array}{l}\text { How would you define "journalistic innovation" or what does } \\
\text { the concept mean to you? }\end{array}$ & $\begin{array}{l}\text { Obtain suggestions for the definition of the concept of journalistic } \\
\text { innovation from researchers that have published academic } \\
\text { studies of new formats. }\end{array}$ \\
\hline $\begin{array}{l}\text { What do you consider to be the most important or significant } \\
\text { new journalistic format (or formats) in current or future } \\
\text { journalism? }\end{array}$ & $\begin{array}{l}\text { Determine which are the most frequently identified formats by } \\
\text { experts. }\end{array}$ \\
\hline
\end{tabular}

The interviewees' responses were analyzed using the qualitative research tool NVivo combined with a manual analysis. Specifically, NVivo allowed the identification of semantic networks of categories and subcategories that in turn helped to group responses in a coherent fashion, while the manual analysis allowed us to refine the results obtained automatically by NVivo and interpret the textual content. 


\section{Results}

The searches conducted show that the equation yielding the greatest number of results was ["interactivity AND (journalism OR newspaper* OR "digital news media"], when combining the results from WoS and Scopus. Therefore, as shown in Table IV, it can be concluded that the greatest number of publications was found for studies tagged under the keyword interactivity. They are followed, in second place, by studies on structured journalism, immersive journalism and visual journalism and, in third place, by studies of virtual reality or augmented. Although the results can be affected by the broadness of the concept studied and the query used, however, at the same time these results are a reflection of trends in academic literature about innovative journalism when tagging manuscripts for its classification.

\begin{tabular}{|c|c|c|}
\hline \multicolumn{3}{|l|}{ SEARCH RESULTS } \\
\hline Equation & $\begin{array}{l}\text { № of articles. } \\
\text { Scopus }\end{array}$ & $\begin{array}{l}\text { № of articles. } \\
\text { Wos }\end{array}$ \\
\hline "structured journalism" OR "immersive journalism" OR "visual journalism" & 62 & 30 \\
\hline $\begin{array}{l}\text { ("virtual reality" OR "augmented reality") AND (journalism OR newspaper* OR "digital news } \\
\text { media") }\end{array}$ & 47 & 7 \\
\hline interactivity AND (journalism OR newspaper* OR “digital news media”) & 88 & 9 \\
\hline ("360 degree video" OR “360 video”) AND (journalism OR newspaper* OR “digital news media”) & 16 & 3 \\
\hline $\begin{array}{l}\text { (newsgame* OR news-game* OR docugame* OR docu-game*) AND (journalism OR newspaper* } \\
\text { OR "digital news media") }\end{array}$ & 9 & 4 \\
\hline
\end{tabular}

Table IV. Search results in Scopus and WoS (April, 2020).

Thus, the study conducted allows us to offer an overview of academic publications studying some of the most recent journalistic formats. Interestingly, it can be seen that more articles in this field were found in Scopus than in Web of Science and, of these, most are focused on structured journalism, immersive journalism, including reports in virtual reality and augmented reality. In contrast, there have been fewer studies examining $360^{\circ}$ video reports and newsgames, mainly because they are more incipient formats and, consequently, most of the publications about these two formats are limited to between 2017 and 2020. It is appropriate to clarify that searches are always based on keywords and, as explained in the methods sections, to ensure coverage of the concepts, we have used overlapping keywords.

\subsection{Bibliometric analysis}

Scientific publications about new digital formats are booming, as shown by the production curve, both in Web of Science and in Scopus. The year 2019 is, in general, the year with the highest scientific production for all the formats considered, followed by 2020 and 2018. If these results are taken into consideration and the fact that, moreover, the data collection for conducting this study was carried out on April 6, 2020, it is reasonable to predict that there will be an exponential increase in scientific production in relation to these formats in forthcoming years.

The journals, Digital Journalism, Journalism Practice and Profesional de la Información are the publications that have published most articles about these new journalistic formats. These three academic journals have a high academic impact in their field, which confirms the commitment to the publication of articles about new journalistic formats by leading journals in the field of journalism. Interestingly, and while in the main articles about journalistic formats and genres are published in social science journals a 
percentage of these articles have also been published in computer science journals, reflecting the fact that the new journalistic formats have a marked technological and interactive component.

The existence is also confirmed of a number of leading authors, whose lines of research include structured journalism, interactive journalism and immersive journalism exploiting augmented reality and virtual reality. The most prolific are Laws with seven publications, Bock, Dahmen and Ksiazek with four, Slater with three and Appelgren with two. In contrast, no authors are credited with more than one publication in Scopus and Web of Science about $360^{\circ}$ videos and journalism or newsgames and docugames.

This same pattern can be seen in the case of the institutions and their respective lines of research; indeed, the University of Texas, the University of Barcelona, Villanova University, the University of Zurich, the Complutense University of Madrid, the University of Santiago de Compostela, the Volda University College and Södertörn University are the leading institutions in this field, their lines of research including structured journalism, immersive journalism, augmented and virtual reality in journalism, and interactivity and journalism.

The fact that a large number of authors and institutions publish studies about new journalistic formats serves to demonstrates their interest in these formats, their investigative potential and their international dimension. In this sense, the United States, Spain and the United Kingdom are the countries that are immersing themselves most in the study of new journalistic formats, followed by Norway, which has a clear academic impact in Web of Science.

A further element that allows us to evaluate the potential and interest for the study of this field is the fact that the studies analyzed present a high degree of funding originating from research projects concerned specifically with journalistic formats. This funding comes mainly from competitive calls launched by public bodies, technology companies and the universities themselves.

Finally, it is worth highlighting the existence of various articles with a large number of citations, which confirms the existence of a number of studies that serve as points of reference in their field. Two such studies are "User engagement with online news: Conceptualizing interactivity and exploring the relationship between online news videos and user comments", with 80 citations, and "Being There in the Midst of the Story: How Immersive Journalism Affects Our Perceptions and Cognitions" with 45 citations.

\subsection{Journalistic innovations, its aspects and challenges}

The academics interviewed indicate that journalistic innovation impacts on four aspects of journalism: 1) information and content; 2) audience; 3 ) methods and resources and 4) news media companies.

In the case of the first of these aspects, they claim that the creation of journalistic content is being governed by new parameters and is being undertaken in environments characterized by these new technologies and digital convergence. They also point to the need to train journalists, introduce content quality controls, and new distribution platforms while seeking to combat disinformation.

As far as the definition and context of the formats are concerned, the researchers interviewed confirm that the new formats represent a different way of handling and delivering information to that exploited by traditional journalism. For the interviewees, the most significant of the new journalistic formats are those that are facilitating the emergence of a new type of polyvalent, multipurpose journalism, that is, a journalism that does not seek to compete with the elements of the conventional media, such as those based on text, audio and the video adapted for consumption on the Internet, buth rather with other uses in which the formats are combined and mixed.

As far as audiences are concerned, the interviewees stress the need to incorporate new elements, including impact, greater empathy and constructive solutions in order to add greater added value to the user experience and transform a reality in which the danger is that media users become saturated and over- 
informed. As regards methods and resources, the experts identify the innovations being made in relation to the different phases of journalism, such as narrativity, loyalty, design, obtaining information, the quality of information and, in a broad sense, to the many different aspects of technological innovation. Finally, in relation to the newspaper business itself, the innovations, they claim, highlight how journalism is evolving as it adapts to new ecosystems and configurations, and implements new ideas in newsrooms in an attempt at building more efficient and sustainable journalistic models. These transformations, moreover, imply changes in workflows and offer novel solutions for the reinvention of a journalism with a new identity.

\subsection{New formats and the most significant innovations}

The researchers interviewed indicate that the new trends and formats impact the following areas: 1) the actual definition and context of the formats themselves; 2) the responses being made to the challenges that the new formats face; 3) the relationship between the formats and their audiences; and, 4) the determination of the most significant formats from the perspective of innovation.

For several years now, new formats applied to journalism have been experimented with, but surprisingly very few can be considered as being truly innovative. In general, these formats exploit new technological solutions; indeed, typically, almost all of them have arrived in conjunction with current technologies such as virtual reality, $5 \mathrm{G}$, etc.

As regards methods and resources, the experts identify the innovations being made in relation to the different phases of journalism, such as narrativity, loyalty, design, obtaining information, the quality of information and, in a broad sense, to the many different aspects of technological innovation.

In discussing audience perceptions of the new formats, the academic researchers interviewed recognize that the reader/user has gone from consuming a personal communication experience, based on carefully corroborated data and information, to demanding immediacy as a value in its own right - that is, "I want it now and I'll have it now" - which means the audience pays little attention to who prepared the information or to its correctness. The interviews carried out confirm that audiences today are participative, interactive and global and that the only guiding principle driving innovation in these new formats should be that of providing quality journalism, that is, innovation perceived as an improvement on the quality of the information being consumed. Part of this requirement has meant that more and more work is being done on information visualization strategies to adapt this content to the different styles and needs of the readers.

\section{Discussion and conclusions}

This study has served to confirm the effectiveness of conducting a systematic review of the literature on new journalistic formats, facilitating a state-of-the-art review of a number of specific aspects of journalistic innovation linked to these new formats, where innovation is understood in a broad sense, including how it has impacted not only the sector but also the information presented by the media and the perception of that information by the audience. Additionally, the study has demonstrated that a systematic review of this kind is an effective tool for identifying the main actors, experts and research centers operating in this field of study, contributing also, in this instance, to the identification of a panel of experts who could subsequently be interviewed. The triangulation of the systematic review with the responses obtained from these expert interviewees is an additional guarantee of the robustness of the conclusions drawn and enables us to compare and contrast the results obtained using each of the methodological tools.

The bibliometric analysis has revealed the basic structural characteristics of the research community publishing on this topic, by detecting the most productive and cited authors, co-authorship patterns, highly cited documents, and the specific topics addressed. Our results indicate that the academic 
literature on new journalistic formats has confirmed the existence of a predominant trend to study, first, the characteristics and uses of these formats; second, their impact on readers; third, the new journalistic ethics that need to emerge in response to them; and, finally, how, and to what content, automation should be applied. Each of these is discussed in more detail below.

First, a good number of studies have been published on the characteristics and uses of new journalistic formats, with a particular emphasis on the development and conceptualization of immersive journalism employing virtual reality and $360^{\circ}$ video (Hardee and McMahan, 2017; Baía-Reis et al., 2018; Steed et al., 2018; Wu, 2019). Many of these works have a special impact on the potential for engagement with victims and for human rights that this type of journalism can bring.

However, much work remains to be done in relation not only to this format, but also to other less studied formats such as structured journalism (Freixa et al., 2017), augmented reality news (Azkunaga et al., 2019; Parra et al., 2017.), visual and photojournalism (Thomson and Greenwood, 2017; Láb and Štefaniková, 2017), data journalism (Young et al., 2018; Weber et al., 2018), and newsgames (RojasTorrijos, 2020; Plewe and Fürsich, 2018).

Second, various authors have successfully studied audience experiences of immersive stories and how they affect users in terms of empathy (Sánchez-Laws, 2020; Steinfeld, 2020; Van Damme et al., 2019), and attention (Palmer, 2020; Van-Damme, 2019) and, more generally, the overall user experience (Shin and Biocca, 2018); however, further case studies are needed of a broad range of news topics employing emerging new technologies that may have a differential impact on the subjective participation of the reader.

Third, we find studies examining the ethics and normative boundaries of the production of news stories using these new journalistic formats, including, for example, Sánchez-Laws and Utne (2019) and Aitamurto (2019); however, additional studies are needed to consolidate a standardized ethics and homogeneous regulations that can address the reality of these new ways of doing journalism. In its turn, a standardized ethics will require researchers that can contribute to studies on the teaching of new media and technological literacy skills and their application in the curricula of schools of journalism, especially in the light of their current scarcity (Mabrook and Singer, 2019; Çatal, 2017).

Finally, we find a number of relevant studies about automated journalism, its characteristics and limitations (Kishore, 2018; Meira, 2016), the tools and technologies for its application (Jones and Jones, 2019) and the identification of fake news (Graves and Anderson, 2020; Lara-Navarra et al., 2020; Kanozia, 2019; Niblock, 2015); however, this body of research has a greater technological and conceptual weight than practical, which makes it difficult to resolve certain key questions in this area of journalism, including, for example, the new skills and the new productive routines required of the journalist and the impact of automated journalism on news media companies, etc.

Our analysis of the bibliometric results obtained shows that a systematic review of the literature examining the main formats currently being developed in journalism allows us to identify the academic impact of these studies. Moreover, the analytical tools of Scopus and Web of Science provide a very complete picture of the main elements impacting scientific production in relation to this specific topic. As a limitation, as our bibliometric analysis was restricted to publications indexed in Scopus and Web of Science, we should acknowledge that our study is inherently biased towards English publications

Our study confirms that analyzing research on new journalistic formats in terms of such indicators as the number of articles, the main academic journals, the most active authors, the most active institutions, and the evolution in the number of citations helps track the different academic characteristics of these articles. Likewise, we have been able to determine the academic evolution of these studies of new formats. Indeed, we have observed an incremental evolution over the last few years; hence, we predict an increase in the production and citation of research of this type in Web of Science and Scopus. In the future, it would be interesting not only to expand the time range of the sample but also to conduct the search for publications 
on journalistic innovation in other databases or among other types of scientific production, not limited solely to academic articles, such as conference proceedings, book chapters, preprints, etc.

Our study has obvious implications for different groups of researchers, confirming as it does the growing emergence and need to study new journalistic formats. Thus, there is a need for further research from the perspective afforded, on the one hand, by scholars of digital journalism, who see these new formats as novel ways for the development of delivering the news, and, on the other, by scholars of emerging technologies in the context of online communication media, who focus on the consumption of news from devices that involve new forms of interactivity. Additionally, scholars of journalistic ethics also have a role to play in this emerging field because, while new formats open up new ways of delivering and consuming news, it is critical that journalists continue to be objective and that journalism does not lose sight of the importance of its sources and the reader's vision, among other elements.

Here, the conducting of semi-structured interviews has allowed us to obtain highly significant insights as to just how journalistic innovation is conceived and what the most significant journalistic formats are today and are likely to be in the future. However, we failed to find a consensual opinion regarding the definition of journalistic innovation, primarily, because the interviewees address the question from many different perspectives, ranging from the points of view of information, the audience and business models to the specific methods and resources of innovation. Yet, we did find that most of the authors interviewed consider journalistic quality to be the differential element when it comes to innovating in the sector along with new forms for targeting the native audiences originating from the new social networks.

Our study confirms that technology serves as the essential vehicle for the further development of journalistic innovation and that this includes the importance of the role played by mobile devices and a range of new gadgets that favor immersion, augmented reality and virtual reality specially, in the context of new ways of doing journalism. Nonetheless, here emerge some of the limitations of this study. On the one hand, related to the query used to find papers focused on innovative journalism. As explained in the methods section, we have used keywords than can overlap and, at the same time, we have not used generic terms, such as innovation, because it could have contributed to create noise in the search results. Future investigations can face this limitation by combining keywords search with a manual search in specific journals aimed to study innovative journalism. On the other hand, although 23 interviewees are a considerable number of interviews, a bigger number and with a more international profile would have enriched the study. Despite this fact, interesting findings have emerged from the interviews. One of the most remarkable is that the interviewees were unable to reach a consensus regarding the most significant features of the new journalistic formats, although among the most frequently identified are immersive journalism, data journalism, the use of interactive infographics, automated journalism and podcasts. Finally, it is worth noting that the interviewees identify a number of challenges that still have to be overcome, above all those concerning the actual use of these formats by journalists to deliver the news and by audiences as they consume the news. The current study provides answers about what and how is innovative journalism being researched and, at the same time, it contributes to generate new questions that will need to be faced by researchers interested on this field.

\section{References}

Aitamurto, T (2019) Normative paradoxes in $360^{\circ}$ journalism: Contested accuracy and objectivity. New Media \& Society 21(1):3-19. DOI: 10.1177/1461444818785153

Anderson, B and Borges-Rey, E (2019) Encoding the UX: User Interface as a Site of Encounter between Data Journalists and their Constructed Audiences. Digital Journalism 7 (9): 1253-1269. DOI: 10.1080/21670811.2019.1607520 
Appelgren, E (2019) Remaining in Control with an Illusion of Interactivity: The Paternalistic Side of Data Journalism. Journalism Practice 13(8): 956-960. DOI: 10.1080/17512786.2019.1642128

Azkunaga, L, Gaztaka, I and Eguskiza, L (2019) Nuevas narrativas en televisión: La Realidad Aumentada en los telediarios de Antena 3. Revista de Comunicación 18 (2): 25-50.DOI: https://doi.org/10.26441/RC18.2-2019-A2

Baía-Reis, A, Vasconcelos-Cunha-Coelho, AF, Castro-Coelho, C (2018) Virtual Reality and Journalism. Digital Journalism 6(8): 1090-1100. DOI: 10.1080/21670811.2018.1502046

Barreda-Ángeles, M (2018) Periodismo inmersivo en España: Análisis de la primera generación de contenidos periodísticos en realidad virtual. Estudios sobre el Mensaje Periodístico 24(2): 1105-1120

Barredo-Ibáñez, D, and Díaz-Cerveró. E (2017) La interactividad en el periodismo digital latinoamericano. Un análisis de los principales cibermedios de Colombia, México y Ecuador. Revista Latina de Comunicación Social 72:273-294. DOI: 10.4185/RLCS-2017-1165

Benítez de García, MJ and Herrera-Damas, S (2018a) El reportaje inmersivo en vídeo en $360^{\circ}$ en los medios periodísticos españoles. Revista de Comunicación 17 (2): 66-100. DOI:

https://doi.org/10.26441/RC17.2-2018-A3

Benítez de García, MJ and Herrera-Damas, S (2018b) El reportaje inmersivo en vídeo $360^{\circ}$ : diseño de un modelo de análisis. El profesional de la información 27(1): 149-161.

https://doi.org/10.3145/epi.2018.ene.14

Booth, A, Papaionnou, D, Sutton. A (2012) Systematic Approaches to a Successful Literature Review. London: Sage.

Carrión, KP and Coronel-Salas, G (2019) Laboratorios: un recurso para la innovación periodística. Revista Iberica de Sistemas e Tecnologias de Informaçao, E20: 477-489.

Caswell, D (2019) Structured Journalism and the Semantic Units of News. Digital Journalism 7(8): 1134-1156. DOI: 10.1080/21670811.2019.1651665

Caswell, D and Dörr, K (2018) Automated Journalism 2.0: Event-driven narratives. Journalism Practice 12(4): 477-496. DOI: 10.1080/17512786.2017.1320773

Coller, X (2000) Estudio de caso. Colección Cuadernos Metodológicos. Madrid: Centro de Investigaciones Sociológicas.

Çatal, Ö (2017) New Technologies Challenging the Practice of Journalism and the Impact of Education: Case of Northern Cyprus. EURASIA Journal of Mathematics, Science and Technology Education 13(11): 7463-7472. DOI: 10.12973/ejmste/79975

Domínguez-Martín, E (2015) Periodismo inmersivo o cómo la realidad virtual y el videojuego influyen en la interfaz e interactividad del relato de actualidad. El profesional de la información 24 (4): 413-423. http://dx.doi.org/10.3145/epi.2015.jul.08

Engebretsen, M (2020) From decoding a graph to processing a multimodal message: Interacting with data visualisation in the news media. Nordicom Review 41(1): 33-50 https://doi.org/10.2478/nor-20200004 
Fernández-Medina, FJ, Proust, V and Núñez-Mussa, E (2018) Consumo incidental de noticias en un contexto de redes sociales y múltiples pantallas. Iberian Journal of Information Systems and Technologies E16(11/2018): 308-320.

Freixa, P, Pérez-Montoro, M and Codina, L (2017) Interacción y visualización de datos en el periodismo estructurado. El profesional de la información 26 (6):1076-1090.

https://doi.org/10.3145/epi.2017.nov.07

García-Avilés, JA (2018) Resultados de la innovación en los laboratorios de medios: el caso de El confidencial. LAB. Profesional de la Información 27(2):359-466.

https://doi.org/10.3145/epi.2018.mar.14

García-Avilés, JA (2021) Review article: Journalism innovation research, a diverse and flourishing field (2000-2020). Profesional de la Información 30(1):1-34. https://doi.org/10.3145/epi.2021.ene.10

Gómez, S, Cabeza, J (2016) El discurso informativo de los newsgames: el caso Bárcenas en los juegos para dispositivos móviles. Cuadernos.info 38:137-148. DOI: 10.7764/cdi.38.593

González-Díez, L, Labarga-Adán, I and Pérez-Cuadrado, P (2019) Gamificación y elementos propios del juego en revistas nativas digitales: el caso de MARCA Plus. Revista de Comunicación 18 (1): 5272. DOI: https://doi.org/10.26441/RC18.1-2019-A3

Grant, MJ and Booth, A (2009) A typology of reviews: an analysis of 14 review types and associated methodologies. Health information and libraries journal 26:91-108. https://doi.org/10.1111/j.14711842.2009.00848.x

Graves, L, and Anderson, CW (2020) Discipline and promote: Building infrastructure and managing algorithms in a structured journalism project by professional fact-checking groups. New media \& society 22(2):342-360. DOI: 10.1177/1461444819856916

Hardee, G and McMahan, R (2017) FIJI: A Framework for the Immersion-Journalism Intersection. Front. ICT 4(21). https://doi.org/10.3389/fict.2017.00021

Hart, C. (2008) Doing a Literature Review: Releasing the Social Science Research Imagination. London: Sage.

Hendriks, P, Daan Wiltink, D, Huiskamp, M, Schaapa, G and Ketelaara. P (2019) Taking the full view: How viewers respond to 360-degree video news. Computers in Human Behavior 91:24-32, https://doi.org/10.1016/j.chb.2018.09.018

Herranz de la Casa, JM, Caerols-Mateo, R and Sidorenko-Bautista, P (2019) La realidad virtual y el vídeo $360^{\circ}$ en la comunicación empresarial e institucional. Revista de Comunicación 18 (2): 177-199. DOI: https://doi.org/10.26441/RC18.2-2019-A9

Herrero-Solana, V and Rodríguez-Domínguez, AM (2015) Periodismo de datos, infografía y visualización de la información: un estudio de El País, El Mundo, Marca y El Correo. Textos universitaris de biblioteconomia i documentació 34:1-7. DOI: http://dx.doi.org/10.1344/BiD2015.34.4

Jones, R and Jones, B (2019). Atomising the News: The (In)Flexibility of Structured Journalism. Digital Journalism 7 (8):1157-1179, DOI: 10.1080/21670811.2019.1609372

Jones, S (2017) Disrupting the narrative: immersive journalism in virtual reality. Journal of media practice 18 (2-3):171-185, https://doi.org/10.1080/14682753.2017.1374677 
Kang, S, O’Brien, E, Villarreal, A, Lee, W and Mahood, C (2019) Immersive Journalism and Telepresence. Digital Journalism 7 (2): 294-313, DOI: 10.1080/21670811.2018.1504624

Kanozia, R (2019) Analysis of Digital Tools and Technologies for Debunking Fake News. Journal of Content, Community \& Communication. 9 (5): 114-122. DOI: 10.31620/JCCC.06.19/16

Kishore, S, Navarro, X, Dominguez, E, De La Peña, N and Slater, M (2018) Beaming into the News: A System for and Case Study of Tele-Immersive Journalism. IEEE Computer Graphics and Applications 26. DOI: 10.1109/MCG.2016.44

Láb, F and Štefaniková, S (2017) Photojournalism in Central Europe. Editorial and Working Practices. Nordicom Review 38(2): 7-23. DOI:10.1515/nor-2017-0411.

Lara-Navarra, P, Falciani, H, Sánchez-Pérez, E and Ferrer-Sapena, A (2020) Information Management in Healthcare and Environment: Towards an Automatic System for Fake News Detection. Int. J. Environ. Res. Public Health 17(3):1-12. DOI:10.3390/ijerph17031066

Mabrook, R. and Singer, J (2019) Virtual Reality, 360 Video, and Journalism Studies: Conceptual Approaches to Immersive Technologies. Journalism Studies 20(14): 2096-2112, DOI:

10.1080/1461670X.2019.1568203

Mañas-Viniegra, L, Veloso, A and Sierra-Sánchez, J (2020) Contenidos inmersivos violentos: investigación con eye tracking en jóvenes universitarios en España y Portugal. El profesional de la información 29(1):1-10. https://doi.org/10.3145/epi.2020.ene.08

Meier, K. (2018). Journalism meets games: Newsgames as a new digital genre. Theory, boundaries, utilization. Journal of Applied Journalism \& Media Studies, 7 (2): 429-444. DOI:

10.1386/ajms.7.2.429_1

Meira, J, Marques, J, Jacob, J, Nóbrega, R, Rodrigues, R, Coelho, A and de-Sousa, A (2016) Video annotation for immersive journalism using masking techniques. 23rd Portuguese Meeting on Computer Graphics and Interaction (EPCGI) $2016: 1-7$.

Meneses-Fernández, MD, and Martín-Gutiérrez. J (2016) Medios de comunicación impresos y Realidad Aumentada, una asociación con futuro. Arbor 192 (777).

http://dx.doi.org/10.3989/arbor.2016.777n1008

Niblock, S (2015) From the high ground to the swamp: A model for immersive journalism research. Journal of Applied Journalism \& Media Studies 4 (2): 223-237. DOI: 10.1386/ajms.4.2.223_1

Paíno-Ambrosio, A, and Rodríguez-Fidalgo, MI (2019) Proposal for a new communicative model in immersive journalism. Journalism 00(0):1-18. DOI: 10.1177/1464884919869710

Palmer, L (2020) "Breaking Free" from the Frame: International Human Rights and the New.York.Times' 360-Degree Video Journalism. Digital Journalism 8(3): 386-403. DOI: $10.1080 / 21670811.2019 .1709982$

Parra, D, Edo, C and Marcos, JC (2017) Análisis de la aplicación de las tecnologías de realidad aumentada en los procesos productivos de los medios de comunicación españoles. Revista Latina de Comunicación Social 72:1670-1688. DOI: 10.4185/RLCS-2017-1240 
Pérez-Seijo, S, Melle-Goyanes, M.and Paniagua-Rojano, FJ (2018) La innovación en la rendición de cuentas de los medios de comunicación de servicio público (PSM). El caso de la CCMA. Revista Latina de Comunicación Social 73:1115-1136. DOI: 10.4185/RLCS-2018-1299

Plewe, C, Fürsich, E (2018). Are Newsgames Better Journalism? Journalism Studies 19(16): 24702487. DOI: 10.1080/1461670X.2017.1351884

Ramirez, T, Zabalondo, B, Aiestaran, and Agirre, A. (2016) The Future of Journalism-Who to Believe? Journalism Practice 10 (1): 71-92. DOI: 10.1080/17512786.2015.1006932

Rojas-Torrijos, JL (2020) Gamification of sports media coverage: an infotainment approach to Olympics and Football World Cups. Communication \& Society 33(1): 29-44. DOI:

10.15581/003.33.1.29-44

Sacco, V, Gorin, V and Schiau, N (2018) Immersive journalism and the migrant crisis: The case of Exils as a mobile radio reportage. Journal of Applied Journalism \& Media Studies 7(1): 197-213. DOI: 10.1386/ajms.7.1.197_1

Salaverría, R (2015) Los labs como fórmula de innovación en los medios. Profesional de la Información, 24(4): 397-404. https://doi.org/10.3145/epi.2015.jul.06

Sánchez-Laws, A (2020) Can Immersive Journalism Enhance Empathy? Digital Journalism 8(2): 213228. DOI: $10.1080 / 21670811.2017 .1389286$

Sánchez-Laws, A, Utne, T (2019) Ethics Guidelines for Immersive Journalism. Frontiers, 6: 1-28, https://doi.org/10.3389/frobt.2019.00028

Sassatelli, L, Winckler, M, Fisichella, T, Dezarnaud, A, Lemaire, J, Aparicio-Pardo, R and Trevisan. D (2020) New interactive strategies for virtual reality streaming in degraded context of use. Computers \& Graphics 86: 27-41. https://doi.org/10.1016/j.cag.2019.10.005

Shin, D, Biocca, F (2018) Exploring immersive experience in journalism. New media \& society 20(8): 2800- 2823. DOI: 10.1177/1461444817733133

Steed, A, Pan, Y, Watson, Z and Slater, M (2018) "We Wait"- The Impact of Character Responsiveness and Self Embodiment on Presence and Interest in an Immersive News Experience. Front. Robot. AI 5(112): 1-14. https://doi.org/10.3389/frobt.2018.00112

Siitonen, M, Uotila, P, Uskali, T, Varsaluoma, J, and Välisalo, T (2019) A pilot study on developing newsgames in collaboration between journalism and computer science students. Nordicom Review 40 (2): 143-155. doi:10.2478/nor-2019-0038.

Steensen, S and Westlund, O (2021) What is Digital Journalism Studies? London: Routledge

Steinfeld, N (2020) To Be there when it Happened: Immersive Journalism, Empathy, and Opinion on Sexual Harassment. Journalism Practice 14(2): 240-258. DOI: 10.1080/17512786.2019.1704842

Sundar, S, Kang, J and Oprean. D (2017) Being There in the Midst of the Story: How Immersive Journalism Affects Our Perceptions and Cognitions. Cyberpsychology, Behavior, and Social Networking 20 (11): 672-682. DOI: 10.1089/cyber.2017.0271

Teixeira, C, Carvalho, B, Soares, M, Neves, A, Lins, A, Agra, J, Martins, V and Soares, G (2015) Usabilility and gameplay in newsgames: a comparative analysis of the genre of documentary published in Brazilian news portals, 6th International Conference on Applied Human Factors and Ergonomics 
(AHFE 2015) and the Affiliated Conferences, AHFE 2015 3:6060-6067. DOI:

10.1016/j.promfg.2015.07.732

Thomson, TJ (2018) The Evolution of Story: How Time and Modality Affect Visual and Verbal Narratives, Visual Communication Quarterly, 25.

Thomson, TJ (2019) In Front of the Lens: The Expectations, Experiences, and Reactions of Visual Journalism's Subjects. Journalism \& Communication Monographs 21(1): 4- 65. DOI:

$10.1177 / 1522637918823261$

Thomson, TJ and Greenwood, K (2017) Beyond Framing. Journalism Practice 11(5): 625-644. DOI: $10.1080 / 17512786.2016 .1152908$

Toursel, A, and Useille, P (2019) Immersive journalism, a "new frontier" of information experience? SBPjor Associação Brasileira de Pesquisadores em Jornalismo 15(4): 350-573.

Trillo-Domínguez, M, and Alberich-Pascual, J (2017) Deconstrucción de los géneros periodísticos y nuevos medios: de la pirámide invertida al cubo de Rubik. El profesional de la información 26(6): 1091-1099. https://doi.org/10.3145/epi.2017.nov.08

Túñez-López, M, Nogueira, AG (2017) Infographics as a Mnemonic structure: Analysis of the informative and identity components of infographic online compositions in Iberic newspapers. Communication \& Society 30 (1): 147-164.

Valles, M (2002) Entrevistas cualitativas. Colección Cuadernos Metodológicos. Madrid: Centro de Investigaciones Sociológicas.

Vállez, M, and Codina, L (2018) Periodismo computacional: evolución, casos y herramientas. El profesional de la información 27(4): 759-768. https://doi.org/10.3145/epi.2018.jul.05

Van-Damme, K, All, A, De-Marez, L, and Van-Leuven, S (2019) $360^{\circ}$ Video Journalism:

Experimental Study on the Effect of Immersion on News Experience and Distant Suffering. Journalism Studies 20(14): 2053-2076. DOI: 10.1080/1461670X.2018.1561208

Vaz, M, and Tejedor, S (2019) Aproximación conceptual al periodismo inmersivo: reflexiones a partir del estudio de caso de seis proyectos periodísticos. Iberian Journal of information Systems and Technologies 20(5): 100-112

Vázquez-Herrero, J, López-García, X (2017) El documental interactivo como formato en los medios audiovisuales: estudio de caso de RTVE y Al Jazeera. Anàlisi. Quaderns de Comunicació i Cultura 57:47-61. DOI: https://doi.org/10.5565/rev/analisi.3100

Vázquez-Herrero, J, Negreira-Rey, MC and López-García, X (2019) La innovación multimedia e interactiva en el ciberperiodismo argentino. Revista de Comunicación 18 (1): 191-214. DOI: https://doi.org/10.26441/RC18.1-2019-A10

Weber, W, Engebretsen, M and Kennedy, H (2018) Data stories. Rethinking journalistic storytelling in the context of data journalism. Studies in Communication Sciences 18.1(2018): 191-206. https://doi.org/10.24434/j.scoms.2018.01.013

Wu, Y (2019) Social news: Connecting virtuality with reality in cyberspace. Journal of Applied Journalism \& Media Studies 8 (3):331-347. DOI: 10.1386/ajms_00005_1 
Yang, J, Lee, I and Lee, S (2019) Is Social VR Possible to be the New Journalism? the Effects of Other Users' Opinions on the Attitude and Perception of Public Opinion When Consuming Contents in VR. International Journal of Innovative Technology and Exploring Engineering, 8 (8S2): 2278-3075

Young, M, Hermida, A and Fulda, J (2018) What Makes for Great Data Journalism? Journalism Practice 12(1): 115-135. DOI: 10.1080/17512786.2016.1270171 